\title{
Bonding in a Group of Hamadryas baboons (Papio hamadryas) under Captivity: Effect of Ambient Temperature, Female Receptiveness and Bacterial Infection
}

\author{
Mahmoud, M. A. \\ Department of Wildlife and Zoo medicine, Faculty of veterinary medicine, \\ Suez Canal University, Ismailia.
}

\begin{abstract}
Bonding in hamadryas baboons (Papio hamadryas) and the effect of daily ambient temperature, female receptiveness and bacterial infection on the structure of family units was studied for six months under captive conditions. The baboons formed three group units, including bachelors, one male unit with three subunits (adult male/female, adult male/2females and adult male/3females) and mother/infant unit. The latter was excluded from the study as the number of observations for this unit was negligible. In general, bachelors' units occupied the highest percentage of observations $(54 \%, \mathrm{p}<0.05)$, while the male/3females sub units recorded the lowest percentage of observations, 3\%). Both male/female and male/2females subunits recorded $36 \%$ and $7 \%$ of occurrence, respectively. The effect of daily ambient temperature on group composition was positively correlated with the formation of bachelors $(\mathrm{R}=0.46)$ while, it was of negligible effect on the formation of other family subunits $(R=-0.03)$. The effect of female receptiveness was positively correlated with the formation of male/3females subunits $(\mathrm{R}=0.5)$ but it was negligible with the formation of other units. Ambient temperature and female receptiveness affected to some degree the bonding structure of baboons. Fecal examination for bacterial infection indicated the presence of Salmonella eneritidis, Klebsiella spp and E.coli within the population with an overall bacterial prevalence of $78 \%$. At group level the highest percentage of Salmonella and Klebsiella positive cases was recorded in male/3females subunit.
\end{abstract}

Key words: baboons, ambient temperature, bonding, family unit, receptiveness, fecal

\section{Introduction}

It is widely accepted that non array of social and grouping human primates exhibit a wide patterns (Colmenares et al, 2006). 
Changes in their population structures and dynamics could be a result of long term adaptation to the existing environmental conditions and to the effects of global climatic cycles (Dunham et al, 2008). Despite the fact that short term studies of small population of primates under captivity may lead to misconception about primate social organization, these studies have proved that some species of primates duplicate their social scenarios observed in the wild (Abegglen, 1984).

Hamadryas baboons, one of the large primates inhabiting a wide range of habitats in Africa and Saudi Arabia, have been extensively studied in the wild as well as under captive conditions. Data on their ecology and social systems have been used in comparative socioecological analyses to assess the variability and plasticity of social systems in closely related primate species (Barett, 2009).

Social interaction among members of the baboon species and their population structure determine the reproductive success of the species in their life time. The social structure of the baboons is strongly based on a multi-level society, of which the basic entity is the one male unit (OMU), consisting of one adult male with one to several females and their off-springs (Eisenberg et al, 1972; Kummer, 1984; Abegglen, 1984 and Schreier and Swedell, 2009). Attached to some OMUs are one or two follower males, but other solitary males may be seen not attached to any OMUs and therefore kept hanging around (Pines et al, 2011). Consequently, almost all mating take place within OMUs, classifying the hamadryads mating system as polygnous and monoandrous (Kummer, 1984; Stammbach, 1987 and Swedell, 2006). The success of males to dominate females and keep well cohesive family units is dependable on male's superiority and strength. Kummer (1995) stated that OMU leaders changed social structure and ability to keep cohesive harem units with age. It is the time when males lose their competitive abilities to monopolize food and secure females.

The present paper describes the bonding characteristics of a captive population of hamadryas baboons with relevance to the structure of family units. Factors that might affect the structure and frequency of occurrence of family units under captivity were also considered. In this regard the effect of ambient temperature and female receptiveness were correlated to the structure and frequency occurrence of family units. Bacterial infection of enterobacteriaceae group was also investigated with relevance to herd structure.

\section{Materials and methods:}

\section{Study site and subjects}

The study was carried out for six months from March 2011 to August 
2011 at Kuwait zoo. A captive population of 66 hamadryas baboons (40: 26ㅇ) housed in a wire mesh outdoor enclosure with concrete floor were differentiated according to sex and age (adult vs. sub adult). The animals, sexually dimorphic, were sexed based on their morphological characteristics (well developed grayish colored manes and apparent gonads of adult males compared to brownish colored females, apparent mammary glands and swollen callosites in receptive females). Preliminary observations for one week were carried out before initiating the study to capture an image of the animals' social behavior under investigation.

\section{Data collection}

Observations to collect data on social organization (composition of family units or so called group structure) of the subjects using a five minute scan sampling (Altman, 1974) took place in the early morning (between 8:00 $\mathrm{h}$ and 9:00 h) when food was dispersed in the enclosure and in the afternoon between $(17: 00 \mathrm{~h}$ and 18:00 $\mathrm{h})$ when the animals were resting. A total of 1728 scans representing 24 scans per day for three days per week for a total of 24 weeks were conducted. Any social interaction by individuals, including grooming, hugging, mounting, grapping, touching and sitting next to the nearest neighbors, was considered social attachment to that neighbor and part of the family unit cohesion
(Bergman and Beehner, 2007). Group structure according to observations was classified into bachelors (only adult and sub-adult males), one male- one female unit, one male- two females unit and one male- three females unit. Receptive females were recognized by the swelling and redness of their callosites (Domb and Page, 2001). The number of receptive females seen in each unit was recorded and correlated to the frequency occurrence of each family unit to determine its effect on group structure. Ambient temperature was recorded every 30 minutes using infra red digital thermometer and its effect on group structure was investigated by correlating temperature records with the frequency of observing each family unit. Bacterial examination was carried out using fresh fecal samples collected from the cage floor in less than $24 \mathrm{~h}$ from defecation (number of samples per group were, bachelors $=28$, male $/$ female $=30$, male $/ 2$ females $=$ 20, male $/ 3$ females $=24$ ) . Fecal samples were cultured for the identification of enterobacteriaceae using differential media ( McConkey, Hekton and EMB agars) and incubated for $24 \mathrm{~h}$ at $37 \mathrm{c}^{\circ}$ to observe the colony morphology. Individual bacterial colonies were further identified by the use of selective and enrichment media according to Christopher and Bruno (2003). Number of positive cases expressed as percentage for 
each bacterial type was related to each family unit.

\section{Data analysis}

The significance of inter-unit variability was tested by the non parametric Kruskal-Wallis test analogous to ANOVA test at $\mathrm{P}<$ 0.05 assuming non normality of the data with the use of Minitab 13 statistical package (Minitab Inc, Penn state university, USA). The correlation coefficient was used to determine degree of association of ambient temperature and female receptiveness with formation of social units.

\section{Results}

\section{Group structure}

The population of baboons was engaged in three group units, bachelors (all adult and sub-adult males) and one male unit/family unit (one dominant male with adult female/s and juveniles of both sexes) with three subunits (male/ female, male/ 2 females, male $/ 3$ females) and mother infant unit. The latter unit was omitted from the analysis as the frequency of its recording was not significant. The mean of the total hours of observations for each unit was calculated as the estimate of the proportion of time the individuals were engaged in this unit. Over all, the baboons observed in $54 \%$ of the total observations in bachelors' units, $36 \%$ in male/ female subunit, $7 \%$ in male/ 2 females subunit and $2 \%$ in male $/ 3$ female subunit. There was a significant difference among proportion of time animals engaged in each family unit in favor of bachelors group $(\mathrm{K}=490.8, \mathrm{DF}=3$, $\mathrm{P}<0.05$ ). Fig 1.

\section{Ambient temperature}

The effect of daily ambient temperature on group structure was tested by correlating ambient temperature records and frequency records of group units using spearman correlation test. The ambient temperature recorded during the study ranged between 38 and 49 degrees. There was a positive correlation between temperature records and the formation of bachelors' units $(\mathrm{R}=0.46)$ but the correlation with other family units was negligible, Fig 2.

\section{Female receptiveness}

The effect of female receptiveness on the formation of one male family unit was tested by correlating data of frequency records of each subunit with data of frequency records of female receptiveness in each subunit using spearman correlation test. There was a positive correlation between female receptiveness $(\mathrm{R}=0.5)$ and the formation male/3females subunits (Fig.3), while the correlation with other family subunits was not significant.

\section{Bacterial examination}

Examination of fecal samples from different groups indicated the presence of salmonella enteriditis, klebsiella spp and Esherechia coli with $78 \%$ overall prevalence of infection. At microbial level 
salmonella prevalence accounted infection with $50 \%$ and $25 \%$, for $37 \%$, klebsiella $14.7 \%$ and respectively. The number of E.coli 26.5\%. At group level positive cases for each bacterial male/3female subunit accounted for type within each animal group is the highest percentage of positive presented in Table 1. cases of salmonella and klebseilla

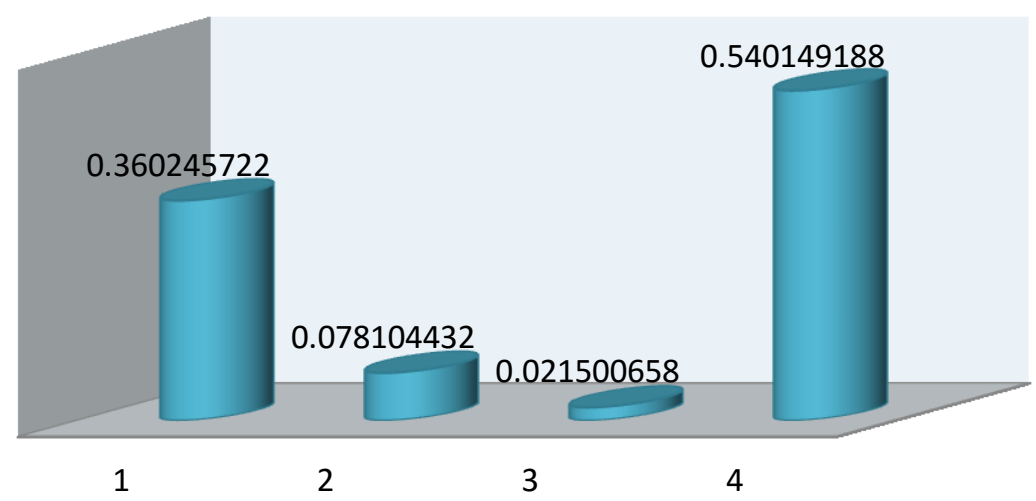

Fig 1: Average values of occurrence for different group structure 1- Male/ female 3-Male/3female

2- Male/2females 4- Bachelors

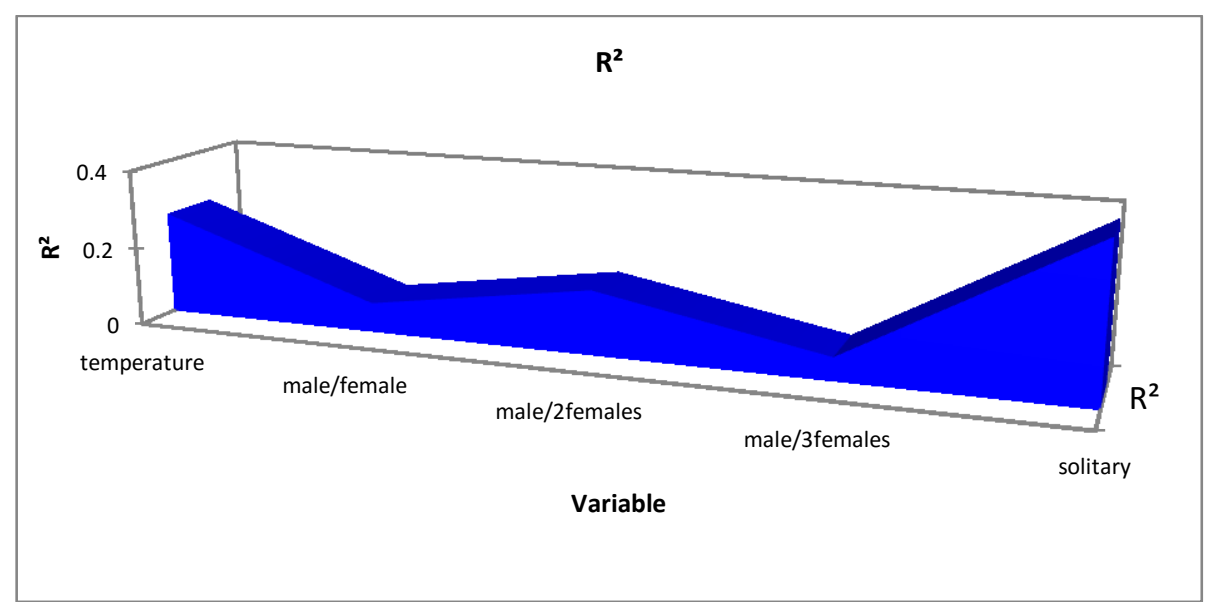

Fig 2: The effect of ambient temperature on group structure $\left(R^{2}\right.$ indictes degree of correlation). 


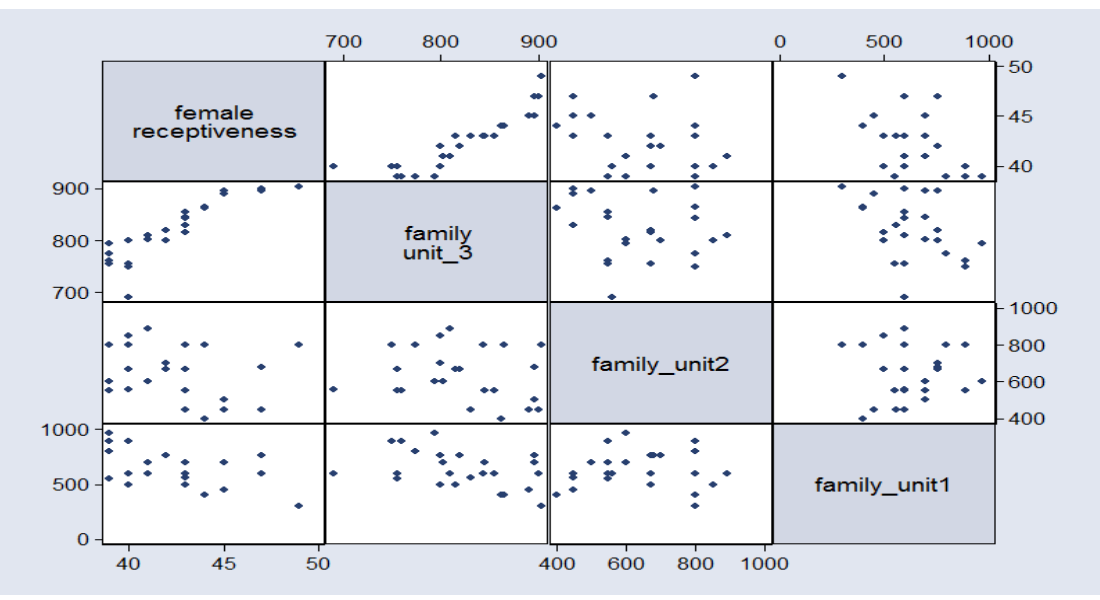

Fig 3: The relationship between female receptiveness and the formation of family units.

Table 1: Summary of positive bacterial cases within each animal group.

\begin{tabular}{|c|c|c|c|c|}
\hline Group & $\begin{array}{c}\text { Number of } \\
\text { samples }\end{array}$ & $\begin{array}{c}\text { Salmonella } \\
\text { +ve samples (\%) }\end{array}$ & $\begin{array}{c}\text { Klebsiella } \\
\text { +ve samples (\%) }\end{array}$ & $\begin{array}{c}\text { E.coli } \\
\text { +ve Samples (\%) }\end{array}$ \\
\hline Bachelors & 28 & $7(25 \%)$ & $2(7 \%)$ & $10(35 \%)$ \\
\hline Male/female & 30 & $12(40 \%)$ & $5(16 \%)$ & $7(23 \%)$ \\
\hline Male/2female & 20 & $7(35 \%)$ & $2(10 \%)$ & $6(30 \%)$ \\
\hline Male/3female & 24 & $12(50 \%)$ & $6(25 \%)$ & $4(16 \%)$ \\
\hline Total & 102 & $38(37 \%)$ & $15(14.7 \%)$ & $27(26.5 \%)$ \\
\hline
\end{tabular}

\section{Discussion:}

Sociality and group composition in primates can be beneficial for individuals because it provides greater protection from competitors, enhance access to resources and creates mating opportunities (Krause and Ruxton, 2002). On the other hand, sociality can be costly for individuals taking the leading role in vigilance and competing over resources and mates (Young and Wang, 2004). The current study indicated that bachelors' group occupied the highest percentage of observations (54\%) where adult and sub adult males joined together in floater groups compared with other family units. Males preferred to form bachelors and become opportunistic (mate and food acquisition when time allows) rather than forming harem units and bearing the costs of protecting these units. Colmenares et al (2009) provided empirical support for the general hypothesis that a large number of males in a group may provide fitness related benefits to the group members provided that they are able to cooperate with each other. Similarly, Zinner et al (2001) worked on wild hamadryas 
baboons in Saudi Arabia and found that adult male baboons can be attached to single one male family unit or to clans of several one male family units to increase their fitness related opportunities. Exposure to predation in the wild and difficult access to patchy food force single males to join one male family unit to share mutual benefits. This case was not recorded in this study because bachelors were predators' safe and secured food without bearing the costs of vigilance and therefore preferred not to join hareem units. Harem groups, in fact rely on their male partners to control and defend females from being taken by bachelor sub adult males (Kifle et al, 2013). The costs of controlling females (vigilance, fighting competition, and dominance) in a very close proximity by harem males may outweigh the benefits (mating) driven by males (Swedell and Schreier, 2009). Ambient temperature in the study, on the other hand, was positively correlated $(\mathrm{R}=0.5)$ with the formation of bachelors' units but it was of negligible effect on the formation of other units. In other words, as the ambient temperature increased in the surrounding environment so the formation of bachelors unit. Males preferred to join bachelors over family units in order to minimize costs of keeping cohesive harem system and be able to thermo regulate under high ambient temperature that sometimes exceeded 45 degrees. Stelzner (1988) stated that baboons in the wild exhibited sedentary behavior by reducing their activities and sitting under shade in hot conditions. Thermo regulatory requirements may influence contact between close individuals and they, therefore, reduce their social interaction and direct contact with partners to cope with high temperature (Brent et al, 2003). At high temperature the harem males in this study dissociated from their harem units and dissolved in bachelors' groups in order to balance between their physiological demands and duties under high temperature. In terms of association based on female readiness to mate, it was evident in this study that a positive correlation was established between female receptivity and the formation of male/ 3 female's subunits. Larger number of receptive females indicated by sexual swelling preferred to gather together under the command of dominant males. It is suggested that receptive females increase their fitness by increasing infant survival in groups having several adult females (Dietz, 2004). As the social integration among receptive females of baboons increases the infants' survival is more likely to increase (Silk et al, 2003, Silk et al, 2009). Although the factors underlying the correlation between social bonding of receptive females and fitness are not fully understood (Silk et al, 2009), there is a growing evidence 
that socially isolated females are more vulnerable to impaired immune system and early death (McClintok et al, 2005). So it can be suggested that the formation of male/ 3 female's subunits in this study was the choice of females rather than the decision of partner males. The higher prevalence of salmonella infection (50\%) and klebsiella infection $(25 \%)$ in male/3female subunit compared to other subunits may be related to the larger number of receptive females seeking mating in this structure. Eren et al (2011) stated that bacterial community and strains are shared between mating partners. Sexual swelling in receptive females in response to hormonal signals increases the surface area for microbes to colonize. Pathogenic microbes spread effectively among socially structured populations (Nunn et al, 2001) where the microbial community may depend on the number of sexually active individuals in the group. Receptivity in females signaled by sexual swelling is associated with multi-male mating and promiscuity. Promiscuity and larger mating group sizes facilitate mucosal contact and transmission of microbes among many mating partners (Stumpf et al, 2011).

In conclusion one would say that captive conditions could influence the decisions of male baboons to become floaters and opportunistic to cope with the artificial environment where they exist with minimum costs. However, increasing fitness by increasing mating opportunities and infant survival is a decision of receptive females rather than the choice of partner males. However large group size with many receptive females seeking for mate poses a high risk of infection which may jeopardize fitness.

\section{References:}

Abegglen, J.J (1984): On socialization of hamadryas baboons. Cranbury, NJ: Associated university presses. 207P.

Altman, J. (1974): Observational studies of behavior: sampling methods. Beh.49:229-267

Barrett, L. (2009): A guide to practical babooning: historical, social, and cognitive contingency, Evolutionary Anthropology. 18, 91102.

Bergman, T., Beehner, J.C. (2007): Social system of a hybrid baboon group ( Papio Anubis X P. hamadryas). Int $\mathrm{J}$ Primatol 25(6): 1313-1330.

Brent, LE, Koban, T., Evans, S.(2003): The influence of temperature on the behavior of captive mother-infant baboons. Behavior 142(2):97-101.

Christopher, K., Bruno, E. (2003): Identification of bacterial species in tested studies for laboratory teaching (ed), O'donnel, M.A., proceedings of the $24^{\text {th }}$ workshops/ conference of the 
association for Biol. Lab. Ed, 24" 103-130.

Colmenares, F., Esteban, M.M, Zaragosa, F.(2006): One-male unit and clans in a colony of hamadryas baboons ( Papio hamadryas): effect of male number and clan cohesion on feeding success. Am J Primatol. 68(1): 21-37.

Dietz, JM (2004): Kinship structure and reproductive skew in cooperatively breeding primates.In: Chapais B and Berman C (ed). Kinship and behavior in primates. Oxford Univ.press. Oxford,UK: 223-241.

Domb, LG and Page, M.(2001): Sexual swelling advertises female quality in wild baboons. Nature 410:204:206.

Dunham, A.E, Erhart, E.M., Overdorff, D.,J., Wright, P.C.(2008): Evaluating effects of deforestation, hunting and El Nino events on a threatened lemur. Biol.Conserv. 144: 287-297.

Eisenberg, J.F, Muchonhirm, N., Rudran, R. (1972): The relation between ecology and social structure in primates. Science 176: 863-874.

Eren, A.m, Zozya, M., Taylor; C.M, Dowd; S.E., Martin, D.H., Ferris; M.J. (2011): Exploring the diversity of Gardnerella vaginalis in the genitourinary tract of monogamus couples. PloS One 6:e26732.

Kifle; Z, Belay; G and Bekel;A (2013): Population size, group composition and behavioral ecology of geladas (Theropithescus gelada) and human gelada conflict in Wonchit valley, Ethiopia. Pakistan journal of biological sciences 16 : 1248-1259.

Krause, J, Ruxton, GD (2002): Living in groups. Oxford university press. Oxford, UK.320 p

Kummer, H. (1984): From laboratory to desert and back: a social system of hamadryas baboons. Anim.beh. 32:965-971.

Kummer, H. (1995). In quest of the sacred baboon. Princeton univ. press. $337 \mathrm{p}$.

McClinkton, Mk, Conzen, M.S.D, Gehlert, S, Masi, C., Olopade, F.(2005): Mammary cancer and social interaction: identifying multiple environments that regulate gene expression throughout the life span. J Ger, Ser B 60:42-41.

Nunn, C.L., Thrall, P.H, Leendertz, F.H, Boesch, C.(2011): The spread of focally transmitted parasites in socially structured populations. PloS One 6: e21677.

Pines, M., Saunders, J., Swedelle, L. (2011): Alternative routes to the leader male role in a multi-level society: followers vs. solitary male baboons. Am J Primatol. 73: 679691.

Schreier, A.L., Swedell, L. (2009): The fourth level of social structure in a multi-level society: ecological and social functions of clans in hamadryas baboons. American journal of primatology, 71, 948955.

Silk, J.B, Alberts, S.C and Altman, J (2003): Social bonds of 
female baboons enhances infants survival. Science 302:1231-1234.

Silk, J.B, Beehner, J.C, Bergman, T.J, Crockford, C., Eng, A.L, Moscovice, L.R, Witing, R.M, Syeforth, R.M and Cheney, D.L (2009): The benefits of social contact among female baboons enhance off-spring survival. Proc.R Soc Lond, Biol.Sc 276:3099-3104.

Stammbach, E. (1987): Desert, forest, montane baboons: multilevel societies. In. Smuts,B.B, Cheney, D.L, Seyfarth, R.M, Wrangham R.W, Struhsaker, T.T.(eds). Primate societies. The university of Chicago press, Chicago, pp 112-120.

Stelzner, J.K.(1988): Thermal effects on movement patterns of yellow baboons (Papio anubilis).

Primates 29(1):91-105.

Stumpf, R.M, Martinez-Mota, R., Milich, K.M, Righini, N., Shattuck, M.R. (2011): Sexual conflict in primates.

Evol.Anthropol. 20; 62-75

Swedell, L. (2006): Strategies of sex and survival in hamadryas baboons: through a female lens. Pearson Prentice Hall. Upper saddle River.220 p

Swedell, L., Schreier, A. (2009): Male aggression toward female hamadryas baboons: conditioning, coercion, and control. In: Muller, MN, Wrangham, RW (ed). Sexual coercion in primates and humans. An evolutionary perspective on male aggression against females. Harvard University press, Cambridge, pp 244-268.

Young, L.J., Wang, Z. (2004): The neurobiology of pair bonding. Nat.Neurosci 7:1048-1054.

Zinner, D., Pelaez, F. , Torker, F.(2001): Group composition and adult sex ratio of hamadryas baboons in central Eriteria. Int.J.of primatology 22(3):415-430. 


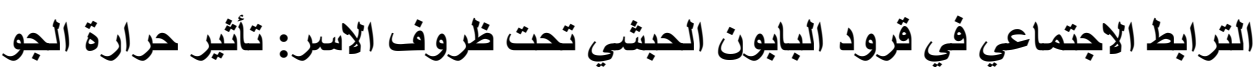
وظّاهرة الثياع في الانثي والبي العدوي البكتيرية

مصطفي احمد محمود

قسم الحباة البرية وحدائق الحبوان كلبة الطب البيطري-- جامعة قناة السوبيس

الملخص العربي

تم دراسة التر ابط الاجتماعي وتأثير كل من حر ارة الجو والثياع في الاناث و العدوي البكتيرية علي التي

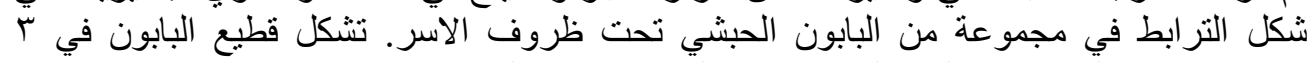

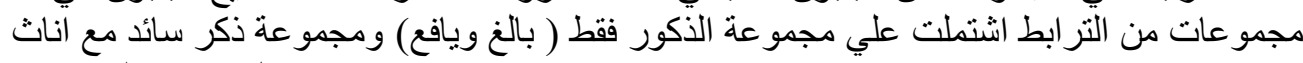

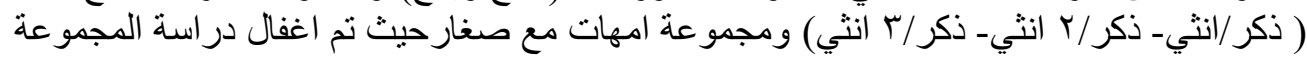

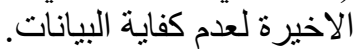

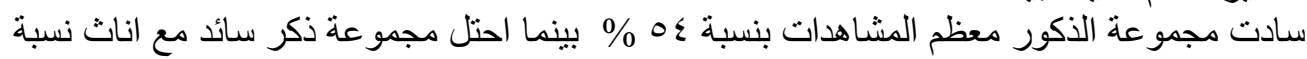

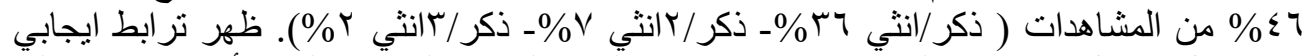

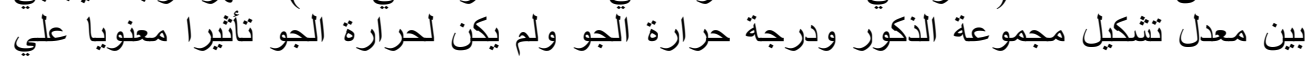

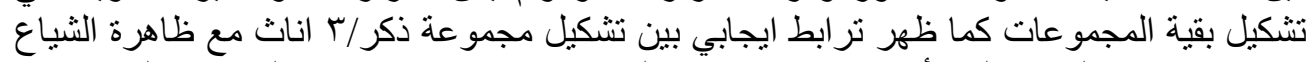

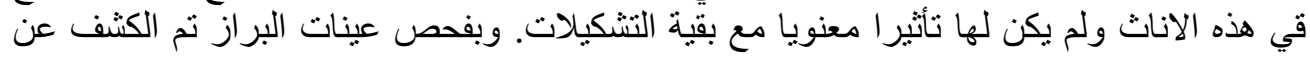
وجود ميكروب السالمونيلا والكليبسيلا و الايكو لاي في القطيع بنسبة اصنابة كلية قدرت بحو الي

\% $\% \wedge$

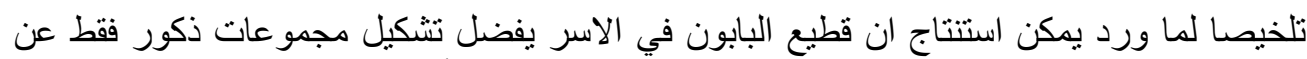

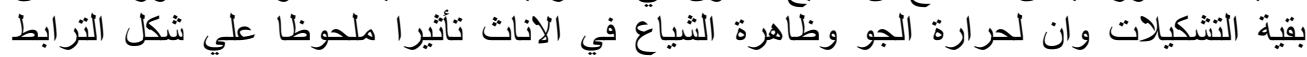

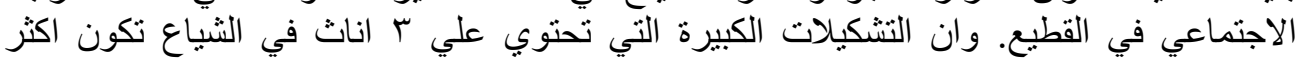

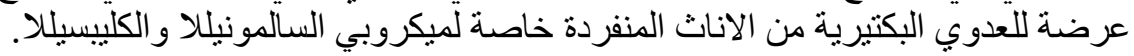

